\title{
SISTEM PAKAR UNTUK DIAGNOSA PENYAKIT KEJIWAAN DENGAN MENGGUNAKAN METODE TEOREMA BAYES
}

\author{
Yul Hendra ${ }^{1}$, Anju Parapat ${ }^{2}$, Dedi Juniansha ${ }^{3}$ \\ Dosen Tetap Program Studi Sistem Informasi, Universitas Banten Jaya \\ Jl. Syeh Nawawi Albantani, Boru, Curug, Kota Serang - Banten \\ E-mail: yulhendra@unbaja.ac.id ${ }^{1}$, anjuparapat@unbaja.ac.id ${ }^{2}$, \\ dedijuniansha@unbaja.ac.id ${ }^{3}$
}

\begin{abstract}
One way to detect psychiatric illnesses is to utilize advanced and modern technology, namely the field of study of Artificial Intelligence (AI) that is able to mimic human intelligence. One part of artificial intelligence is an expert system (expert system). In general the expert system (expert system) is one of the fields of computer science that utilizes computers so that they can behave intelligently like humans. This system seeks to adopt human knowledge into computers, so that computers can solve problems as is usually done by experts. The expert system will provide a list of symptoms until they can identify the object based on the answers received. This system is intended for early diagnosis of 4 types of mental illness, namely: Schizophrenia, Psychopaths, Obsessive and Depression. The processed data is obtained from psychiatrists. and the expected outcome of this system is to be able to detect psychiatric diseases early with the help of a system in which knowledge is taken from the knowledge of a psychiatrist.
\end{abstract}

Keywords: Detection, Expert System, Mental

\section{PENDAHULUAN}

Gangguan jiwa adalah sindrom atau pola pikir yang secara klinis bermakna yang berkaitan langsung distress (penderitaan) dan menimbulkan hendaya (disabilitas) pada satu atau lebih fungsi kehidupan manusia. Fungsi jiwa yang terganggu meliputi fungsi biologis, psikologis, sosial dan spiritual. Secara umum gangguan fungsi jiwa yang dialami seseorang individu dapat terlihat dari penampilan, komunikasi, proses berpikir, interaksi dan aktifitasnya sehari-hari

Salah satu cara untuk mendekteksi penyakit kejiwaan tersebut adalah dengan memanfaatkan teknologi canggih dan modern yaitu bidang studi Artificial Intelligence (AI) yang mampu meniru kecerdasan manusia. Salah satu bagian dari kecerdasan buatan tersebut adalah sistem pakar (expert system). Secara umum 
sistem pakar (expert system) adalah salah satu bidang ilmu komputer yang mendayagunakan komputer sehingga dapat berprilaku cerdas seperti manusia. Sistem ini berusaha mengadopsi pengetahuan manusia ke komputer, agar komputer dapat menyelesaikan masalah seperti yang biasa dilakukan oleh para ahli. Sistem pakar akan memberi daftar gejala-gejala sampai bisa mengidentifikasikan suatu objek berdasarkan jawaban yang diterima. Dengan adanya sistem pakar ini diharapkan akan memberikan kemudahan kepada masyarakat untuk melakukan pendeteksian secara dini terhadap penyakit gangguan kejiwaan.

\section{METODE PENELITIAN}

Dalam penelitian ini digunakan Teorama Bayes, teorema Bayes adalah sebuah teorema dengan dua penafsiran berbeda. Dalam penafsiran Bayes, teorema ini menyatakan seberapa jauh derajat kepercayaan subjektif harus berubah secara rasional ketika ada petunjuk baru.

Langkah-langkah perhitungan menggunakan metode Bayes adalah sebagai berikut:

1. Menghitung jumlah kelas/label

2. Menghitung jumlah kasus perkelas

3. Mengalikan semua hasil variable kelas

4. Membandingkan hasil perkelas

Untuk Mencari probabilitas gunakan rumus:

$\mathrm{p}(\mathrm{x})=$ jumlah kejadian berhasil/jumlah semua kejadian.

Contoh: ada 10 jenis ikan tawar, hanya ada 3 jenis ikan yang bisa hidup di daerah gorontalo.

Berapa peluang ikan yang bisa hidup di gorontalo?

$\mathrm{p}($ gorontalo $)=3 / 10=0.3$

\section{Teorema Bayes}

Dengan:

$\mathrm{p}(\mathrm{Hi} \mid \mathrm{E})=$ probabilitas hipotesis Hi benar jika diberikan evidence (fakta) E

$\mathrm{p}(\mathrm{E} \mid \mathrm{Hi})=$ probabilitas munculnya evidence (fakta) $\mathrm{E}$ jika diketahui hipotesis Hi benar 
$\mathrm{p}(\mathrm{Hi})=$ probabilitas hipotesis $\mathrm{Hi}$ (menurut hasil sebelumnya) tanpa memandang evidence (fakta) apapun $n=$ jumlah hipotesis yang mungkin

Setelah selesai melakukan perhitungan/uji coba hipotesis, maka akan mendapatkan 1 atau lebih evidence(fakta) baru, maka:

dengan :

$\mathrm{e}=$ evidence lama

$\mathrm{E}=$ evidence atau observasi baru

$\mathrm{p}(\mathrm{H} \mid \mathrm{E}, \mathrm{e})=$ probabilitas hipotesis $\mathrm{H}$ benar jika muncul evidence baru $\mathrm{E}$ dari evidence lama e

$\mathrm{p}(\mathrm{H} \mid \mathrm{E})=$ probabilitas hipotesis $\mathrm{H}$ benar jika diberikan evidence $\mathrm{E}$.

$\mathrm{p}(\mathrm{e} \mid \mathrm{E}, \mathrm{H})=$ kaitan antara e dan $\mathrm{E}$ jika hipotesis benar

$\mathrm{P}(\mathrm{e} \mid \mathrm{E})=$ kaitan antara e dan $\mathrm{E}$ tanpa memandang hipotesis apapun

Tahapan di dalam melakukan metode penelitian ini adalah sebagai berikut :

1. Perencanaan (System Planning)

Lebih menekankan kepada aspek studi kelayakan pengembangan sistem. Adapun aktivitas-aktivitas yang dilakukan pada tahapan ini adalah :

a. Kick Of Meeting (Pertemuan awal)

Pertemuan awal antara tim pengembangan dengan dokter spesialis jiwa guna menyepakati tentang aturan main yang harus dijalankan oleh kedua belah pihak

b. Melakukan proses identifikasi terhadap permasalahan yang bisa diselesaikan melalui pengembangan sistem

c. Menentukan prioritas teknologi dan pemilihan aplikasi.

\section{Analisis Sistem (Sistem Analisys)}

Pada tahap ini aktivitas yang dilakukan adalah sebagai berikut :

a. Melakukan pengambilan data-data mentah untuk bahan analis

b. Mengumpulkan studi-studi literature, sebagai referensi penyelesaian masalah 
c. Mengklasifikasi masalah, peluang serta solusi yang mungkin bisa diterapkan pada kasus ini

d. Melakukan analisa kebutuhan dan membuat batasan sistem

e. Mendefenisikan kebutuhan sistem

3. Perancangan Sistem (System Design)

Pada tahap ini sistem mulai dirancang secara detail dengan melakukan pemodelan terhadap sistem yang akan dirancang, pada tahap ini aktivitas yang dilakukan adalah :
a. Merancang Output dari sistem
b. Merancang Database sistem
c. Merancang interface dari sistem
d. Merancangan pengaturan hak akses pengguna sistem

4. Implementasi Sistem (System Implementation)

Pada tahap ini hasil dari tahap perancangan akan coba di realisasikan dalam bentuk pembuatan sistem secara nyata, adapun aktivitas yang dilakukan pada tahapan ini adalah :
a. Pembuatan Output sistem sesuai perencanaan
b. Pembuatan Database sesuai konsep
c. Pembuatan tampilan aplikasi sesuai keiiginan pengguna
d. Pembuatan logic daripada pengaturan hak akses user
e. Pengujian sistem

\section{PEMBAHASAN DAN HASIL}

\section{A. Pembahasan}

\section{Tabel Penyakit}

Membuat tabel jenis jenis penyakit untuk mengList jenis-jenis penyakit jiwa dan memberi kode terhadap jenis penyakit tersebut.

Tabel 1. Tabel Penyakit

\begin{tabular}{|c|l|}
\hline Kode & \multicolumn{1}{|c|}{ Nama Penyakit } \\
\hline P01 & Skizofrenia \\
\hline P02 & Psikopat \\
\hline
\end{tabular}




\begin{tabular}{|l|l|}
\hline P03 & Obsesif \\
\hline P04 & Depresi \\
\hline
\end{tabular}

\section{Tabel Gejala}

Membuat tabel gejala untuk menglist data-data gejala penyakit jiwa dan memberi kode terhadap gejala-gejala tersebut.

Tabel 2. Tabel Gejala

\begin{tabular}{|c|l|}
\hline Kode & \multicolumn{1}{|c|}{ Gejala } \\
\hline G01 & Halusinasi dan waham \\
\hline G02 & Kurangnya keinginan ntuk melakukan aktivitas sehari-hari \\
\hline G03 & Kurangnya kemampuan bekerja \\
\hline G04 & Kurangnya keinginan untuk melakukan hubungan sosial \\
\hline G05 & $\begin{array}{l}\text { Berkurangnya kemampuan dalam berkomunikasi dengan orang } \\
\text { lain }\end{array}$ \\
\hline G06 & Sering Berbohong \\
\hline G07 & Egosentris dan menganggap dirinya hebat \\
\hline G08 & Tidak punya rasa sesal, rasa bersalah \\
\hline G09 & Senang melakukan pelanggaran di waktu kecil \\
\hline G10 & Sikap acuh tak acuh terhadap masyarakat \\
\hline G11 & Kurang Empati \\
\hline G12 & Kecemasan dan rasa kekawatiran yang berlebihan \\
\hline G13 & Rasa takut terhadap asap atau bahaya polutan berlebihan \\
\hline G14 & Tidak stabil secara emosional \\
\hline G15 & Merasa putus asa \\
\hline G16 & Selalu merasa lelah tidak bertenaga \\
\hline G17 & Mengalami pusing dan nyeri tanpa penyebab yang jelas \\
\hline G18 & Menurunnya selera makan \\
\hline
\end{tabular}




\section{Tabel Diagnosa}

Membuat Tabel diagnosa untuk mengklasifikasikan penyakit berdasarkan nama penyakit, gejala dan solusinya.

Tabel 3. Tabel Diagnosa

\begin{tabular}{|c|c|c|c|}
\hline No & $\begin{array}{c}\text { Nama } \\
\text { Penyakit }\end{array}$ & Gejala Penyakit & Solusi \\
\hline 1 & Skizofrenia & $\begin{array}{l}\text { 1. Halusinasi dan waham } \\
\text { 2. Kurangnya keinginan untuk } \\
\text { melakukan aktivitas sehari-hari } \\
\text { 3. Kurangnya kemampuan bekerja } \\
\text { 4. Kurangnya keinginan untuk } \\
\text { melakukan hubungan sosial } \\
\text { 5. Berkurangnya kemampuan dalam } \\
\text { berkomunikasi dengan orang lain }\end{array}$ & $\begin{array}{l}\text { 1. } \text { Terapi Medikasi } \\
\text { 2. Psikoterapi } \\
\text { 3. } \text { Rehabilitasi }\end{array}$ \\
\hline 2 & Psikopat & $\begin{array}{l}\text { 1. Sering berbohong } \\
\text { 2. Egosentris dan menganggap } \\
\text { dirinya hebat } \\
\text { 3. Tidak punya rasa sesal, rasa } \\
\text { bersalah } \\
\text { 4. Senang melakukan pelanggaran di } \\
\text { waktu kecil } \\
\text { 5. Sikap acuh tak acuh terhadap } \\
\text { masyarakat } \\
\text { 6. Kurang empati }\end{array}$ & $\begin{array}{l}\text { 1. Psyco Analisys } \\
\text { 2. Terapi secara } \\
\text { berkelompok } \\
\text { 3. Psyco Drama } \\
\text { 4. Psyco Surgery } \\
\text { 5. Electroconvulsive } \\
\text { Therapy (ECT) } \\
\text { 6. Obat-obatan }\end{array}$ \\
\hline 3 & Obsesif & $\begin{array}{l}\text { 1. Kecemasan dan rasa kekawatiran } \\
\text { yang berlebihan } \\
\text { 2. Rasa takut terhadap asap atau } \\
\text { bahaya polutan berlebihan }\end{array}$ & $\begin{array}{l}\text { 1.Terapi perilaku } \\
\text { kognitif } \\
\text { 2.Obat anti Depresan }\end{array}$ \\
\hline 4 & Depresi & $\begin{array}{l}\text { 1. Kecemasan dan kekhawatiran yang } \\
\text { berlebihan } \\
\text { 2. Tidak stabil secara emosional } \\
\text { 3. Merasa putus asa } \\
\text { 4. Selalu merasa lelah tidak } \\
\text { bertenaga } \\
\text { 5. Mengalami pusing dan nyeri tanpa } \\
\text { penyebab yang jelas } \\
\text { 6. Menurunnya selera makan }\end{array}$ & $\begin{array}{l}\text { 1. Psikoterapi } \\
\text { 2. Memberikan obat } \\
\text { anti Depresan } \\
\text { 3. Memberikan } \\
\text { Terapi kejut } \\
\text { Listrik }\end{array}$ \\
\hline
\end{tabular}




\section{Tabel Matrik Gejala}

Untuk mengetahui ada atau tidaknya gejala yang sama dari beberapa penyakit yang sama maka dapat dilihat dengan matrik gejala

Tabel 4. Tabel Matrik Gejala

\begin{tabular}{|c|c|c|c|c|c|}
\hline Kode & Gejala & $\begin{array}{l}\text { Skizo- } \\
\text { frenia }\end{array}$ & Psikopat & Obsesif & Depresi \\
\hline G01 & Halusinasi dan waham & $*$ & & & \\
\hline G02 & $\begin{array}{l}\text { Kurangnya } \\
\text { melakukanginan ntuk } \\
\text { haktivitas sehari- }\end{array}$ & $*$ & & & \\
\hline G03 & $\begin{array}{l}\text { Kurangnya kemampuan } \\
\text { bekerja }\end{array}$ & $*$ & & & \\
\hline G04 & $\begin{array}{l}\text { Kurangnya keinginan untuk } \\
\text { melakukan hubungan sosial }\end{array}$ & $*$ & & & \\
\hline G05 & $\begin{array}{l}\text { Berkurangnya kemampuan } \\
\text { dalam berkomunikasi dengan } \\
\text { orang lain }\end{array}$ & $*$ & & & \\
\hline G06 & Sering Berbohong & & $*$ & & \\
\hline G07 & $\begin{array}{l}\text { Egosentris dan menganggap } \\
\text { dirinya hebat }\end{array}$ & & $*$ & & \\
\hline G08 & $\begin{array}{l}\text { Tidak punya rasa sesal, rasa } \\
\text { bersalah }\end{array}$ & & $*$ & & \\
\hline G09 & $\begin{array}{l}\text { Senang melakukan } \\
\text { pelanggaran di waktu kecil }\end{array}$ & & $*$ & & \\
\hline G10 & $\begin{array}{l}\text { Sikap acuh tak acuh terhadap } \\
\text { masyarakat }\end{array}$ & & $*$ & & \\
\hline G11 & Kurang Empati & & $*$ & & \\
\hline G12 & $\begin{array}{l}\text { Kecemasan dan rasa } \\
\text { kekawatiran yang berlebihan }\end{array}$ & & & $*$ & $*$ \\
\hline G13 & $\begin{array}{l}\text { Rasa takut terhadap asap atau } \\
\text { bahaya polutan berlebihan }\end{array}$ & & & $*$ & \\
\hline G14 & Tidak stabil secara emosional & & & & $*$ \\
\hline G15 & Merasa putus asa & & & & $*$ \\
\hline G16 & $\begin{array}{l}\text { Selalu merasa lelah tidak } \\
\text { bertenaga }\end{array}$ & & & & $*$ \\
\hline G17 & $\begin{array}{l}\text { Mengalami pusing dan nyeri } \\
\text { tanpa penyebab yang jelas }\end{array}$ & & & & $*$ \\
\hline G18 & Menurunnya selera makan & & & & $*$ \\
\hline
\end{tabular}




\section{Pohon Keputusan}

Diagram pohon keputusan akan mempermudah untuk menyusun basis pengetahuan dan aturan serta menentukan faktor kepastian dari setiap pelaksanaan identifikasi gejala pada penyakit jiwa

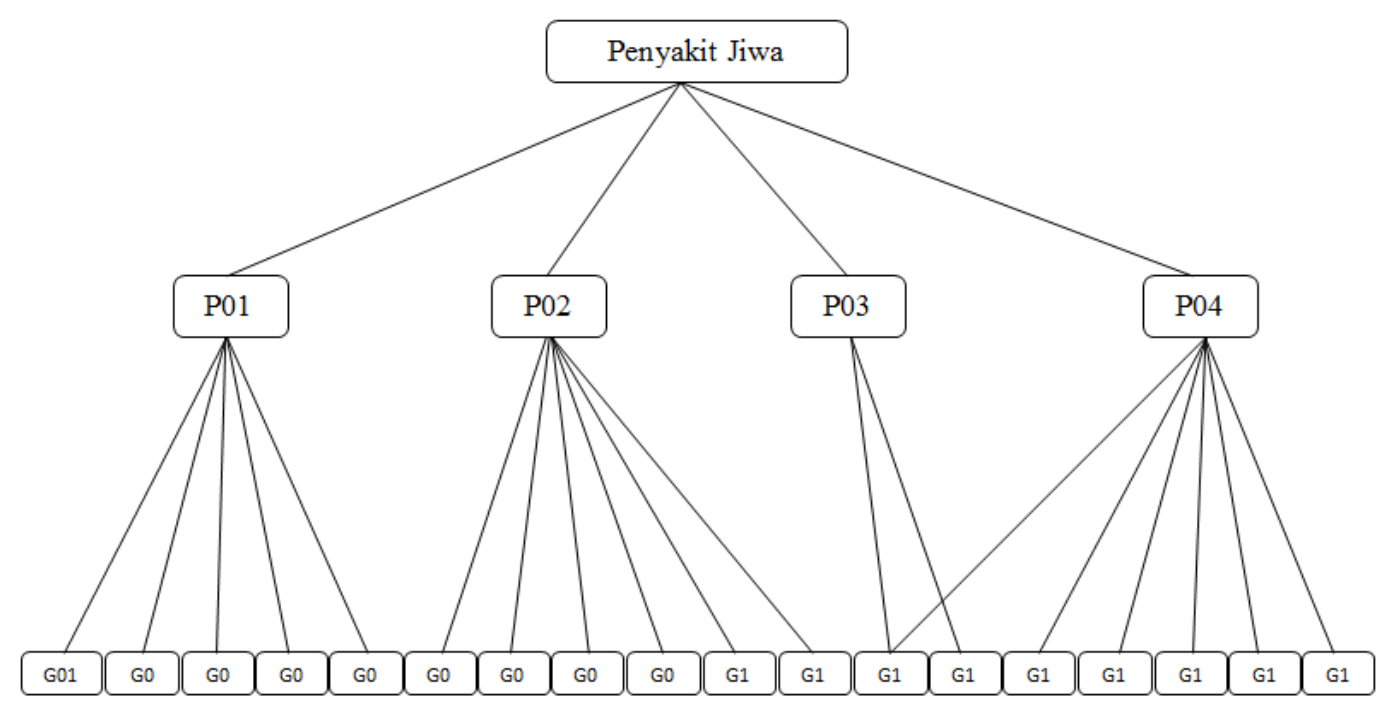

Gambar 1. Pohon Keputusan

\section{Aturan / Rule}

Adapun aturan atau rule adalah sebagai berikut :

\section{Rule 1 :}

IF G01 AND

IF G02 AND

IF G03 AND

IF G04 AND

IF G05 THEN P01

\section{Rule 2 :}

IF GO6 AND

IF G07 AND

IF G08 AND

IF G09 AND

IF G10 AND

IG G11 THEN P02 


\section{Rules 3 :}

IF G12 AND

IF G13 THEN P03

\section{Rules 4 :}

IF G12 AND

IF G14 AND

IF G15 AND

IF G16 AND

IF G17 AND

IF G18 THEN P04

7. Menghitung Probabilitas Dari Gejala, Probabilitas Penyakit dan Gejala

\section{Terhadap Penyakit}

Mencari Probabilitas Gejala

$$
\begin{aligned}
& P(E)=\frac{n}{N} \\
& \text { 1. } P\left(E_{1}\right)=\frac{1}{18}=0.555 \\
& \text { 2. } P\left(E_{2}\right)=\frac{1}{18}=0.555 \\
& \text { 3. } P\left(E_{3}\right)=\frac{1}{18}=0.555 \\
& \text { 4. } P\left(E_{4}\right)=\frac{1}{18}=0.555 \\
& \text { 5. } P\left(E_{5}\right)=\frac{1}{18}=0.555 \\
& \text { 6. } P\left(E_{6}\right)=\frac{1}{18}=0.555 \\
& \text { 7. } P\left(E_{7}\right)=\frac{1}{18}=0.555 \\
& \text { 8. } P\left(E_{8}\right)=\frac{1}{18}=0.555 \\
& \text { 9. } P\left(E_{9}\right)=\frac{1}{18}=0.555 \\
& \text { 10. } P\left(E_{10}\right)=\frac{1}{18}=0.555 \\
& \text { 11. } P\left(E_{11}\right)=\frac{1}{18}=0.555 \\
& \text { 12. } P\left(E_{12}\right)=\frac{2}{18}=0.111 \\
& \text { 13. } P\left(E_{13}\right)=\frac{1}{18}=0.555 \\
& \text { 14. }\left(E_{14}\right)=\frac{1}{18}=0.555 \\
& \text { 15. } P\left(E_{15}\right)=\frac{1}{18}=0.555 \\
& \text { 16. } P\left(E_{16}\right)=\frac{1}{18}=0.555
\end{aligned}
$$




$$
\begin{aligned}
& \text { 17. } P\left(E_{17}\right)=\frac{1}{18}=0.555 \\
& \text { 18. } P\left(E_{18}\right)=\frac{1}{18}=0.555
\end{aligned}
$$

\section{Probabilitas}

Untuk melihat kemungkinan yang bisa terjadi pada gejala maka dapat kita lihat pada tabel berikut ini:

Tabel 5. Probabilitas Gejala

\begin{tabular}{|c|c|c|c|c|c|}
\hline \multirow{2}{*}{ No } & \multirow{2}{*}{ Probabilitas } & \multicolumn{4}{|c|}{ Hipotesis } \\
\cline { 3 - 6 } & & $\mathbf{i}=\mathbf{1}$ & $\mathbf{i}=\mathbf{2}$ & $\mathbf{i}=\mathbf{3}$ & $\mathbf{i}=\mathbf{4}$ \\
\hline 1 & $\mathbf{P}(\mathrm{Hi})$ & $\mathbf{0 . 0 6 6}$ & $\mathbf{0 . 3 3 3}$ & $\mathbf{0 . 1 1 1}$ & $\mathbf{0 . 3 3 3}$ \\
\hline 2 & $\mathrm{P}\left(\mathrm{E}_{1} \mid \mathrm{Hi}\right)$ & 0.555 & 0.555 & 0.555 & 0.555 \\
\hline 3 & $\mathrm{P}\left(\mathrm{E}_{2} \mid \mathrm{Hi}\right)$ & 0.555 & 0.555 & 0.555 & 0.555 \\
\hline 4 & $\mathrm{P}\left(\mathrm{E}_{3} \mid \mathrm{Hi}\right)$ & 0.555 & 0.555 & 0.555 & 0.555 \\
\hline 5 & $\mathrm{P}\left(\mathrm{E}_{4} \mid \mathrm{Hi}\right)$ & 0.555 & 0.555 & 0.555 & 0.555 \\
\hline 6 & $\mathrm{P}\left(\mathrm{E}_{5} \mid \mathrm{Hi}\right)$ & 0.555 & 0.555 & 0.555 & 0.555 \\
\hline 7 & $\mathrm{P}\left(\mathrm{E}_{6} \mid \mathrm{Hi}\right)$ & 0.555 & 0.555 & 0.555 & 0.555 \\
\hline 8 & $\mathrm{P}\left(\mathrm{E}_{7} \mid \mathrm{Hi}\right)$ & 0.555 & 0.555 & 0.555 & 0.555 \\
\hline 9 & $\mathrm{P}\left(\mathrm{E}_{8} \mid \mathrm{Hi}\right)$ & 0.555 & 0.555 & 0.555 & 0.555 \\
\hline 10 & $\mathrm{P}\left(\mathrm{E}_{9} \mid \mathrm{Hi}\right)$ & 0.555 & 0.555 & 0.555 & 0.555 \\
\hline 11 & $\mathrm{P}\left(\mathrm{E}_{10} \mid \mathrm{Hi}\right)$ & 0.555 & 0.555 & 0.555 & 0.555 \\
\hline 12 & $\mathrm{P}\left(\mathrm{E}_{11} \mid \mathrm{Hi}\right)$ & 0.111 & 0.111 & 0.111 & 0.111 \\
\hline 13 & $\mathrm{P}\left(\mathrm{E}_{12} \mid \mathrm{Hi}\right)$ & 0.555 & 0.555 & 0.555 & 0.555 \\
\hline 14 & $\mathrm{P}\left(\mathrm{E}_{13} \mid \mathrm{Hi}\right)$ & 0.555 & 0.555 & 0.555 & 0.555 \\
\hline 15 & $\mathrm{P}\left(\mathrm{E}_{14} \mid \mathrm{Hi}\right)$ & 0.555 & 0.555 & 0.555 & 0.555 \\
\hline 16 & $\mathrm{P}\left(\mathrm{E}_{15} \mid \mathrm{Hi}\right)$ & 0.555 & 0.555 & 0.555 & 0.555 \\
\hline 17 & $\mathrm{P}\left(\mathrm{E}_{16} \mid \mathrm{Hi}\right)$ & 0.555 & 0.555 & 0.555 & 0.555 \\
\hline 18 & $\mathrm{P}\left(\mathrm{E}_{17} \mid \mathrm{Hi}\right)$ & 0.555 & 0.555 & 0.555 & 0.555 \\
\hline 19 & $\mathrm{P}\left(\mathrm{E}_{18} \mid \mathrm{Hi}\right)$ & 0.555 & 0.555 & 0.555 & 0.555 \\
\hline & & & & & \\
\hline 1 & & & & & \\
\hline & & & & & \\
\hline
\end{tabular}

\section{Rancangan Database}

Rancangan tabel ini pemaparan dari field field yang ada pada Entity Relationship diagram adalah sebagai berikut : 
1. Nama Tabel : bayes_penyakit

Primary Key : : kode_penyakit

Foregin Key

Tabel 6. Data Penyakit

\begin{tabular}{|l|l|l|l|l|}
\hline No & Nama Field & Type & Panjang & Keterangan \\
\hline 1 & node_penyakit & char & 2 & Kode Penyakit \\
\hline 2 & nama_penyakit & varchar & 50 & Nama Penyakit \\
\hline 3 & bobot & char & 4 & Bobot penyakit \\
\hline 4 & keterangan & varchar & 255 & Keterangan \\
\hline
\end{tabular}

2. Nama Tabel : bayes_gejala

Primary Key : : kode_gejala

Foregin Key

Tabel 7. Data Gejala

\begin{tabular}{|l|l|l|l|l|}
\hline No & Nama Field & Type & Panjang & Keterangan \\
\hline 1 & Kode_gejala & char & 4 & Kode Gejala \\
\hline 2 & Nama_gejala & varchar & 50 & Nama Gejala \\
\hline
\end{tabular}

3. Nama Tabel : bayes_aturan

Primary Key : ID

Foreign Key : kode_penyakit, kode_gejala

Tabel 8. Data Aturan

\begin{tabular}{|l|l|l|l|l|}
\hline No & Nama Field & Type & Panjang & Keterangan \\
\hline 1 & ID & varchar & 16 & Id aturan \\
\hline 2 & Kode_penyakit & varchar & 16 & Kode penyakit \\
\hline 3 & Kode_gejala & varchar & 16 & Kode gejala \\
\hline 4 & nilai & double & 4 & nilai \\
\hline
\end{tabular}

4. Nama Tabel : bayes_user

Primary key : id_user

Foreign key

Foreign key 
Tabel 9. Data User

\begin{tabular}{|l|l|l|l|l|}
\hline No & Nama Field & Type & Panjang & Keterangan \\
\hline 1 & Id_user & int & 11 & Id user \\
\hline 2 & user & varchar & 50 & user \\
\hline 3 & pass & varchar & 50 & pass \\
\hline 4 & email & varchar & 50 & email \\
\hline 5 & nama & varchar & 50 & Nama user \\
\hline 6 & alamat & varchar & 255 & Alamat user \\
\hline
\end{tabular}

\section{B. Hasil}

\section{Menu Penyakit}

Pada form ini kita dapat melihat daftar list penyakit, untuk menambahkan data penyakit yang baru tinggal mengklik tombol tambah maka akan muncuk form untuk memasukan data penyakit baru

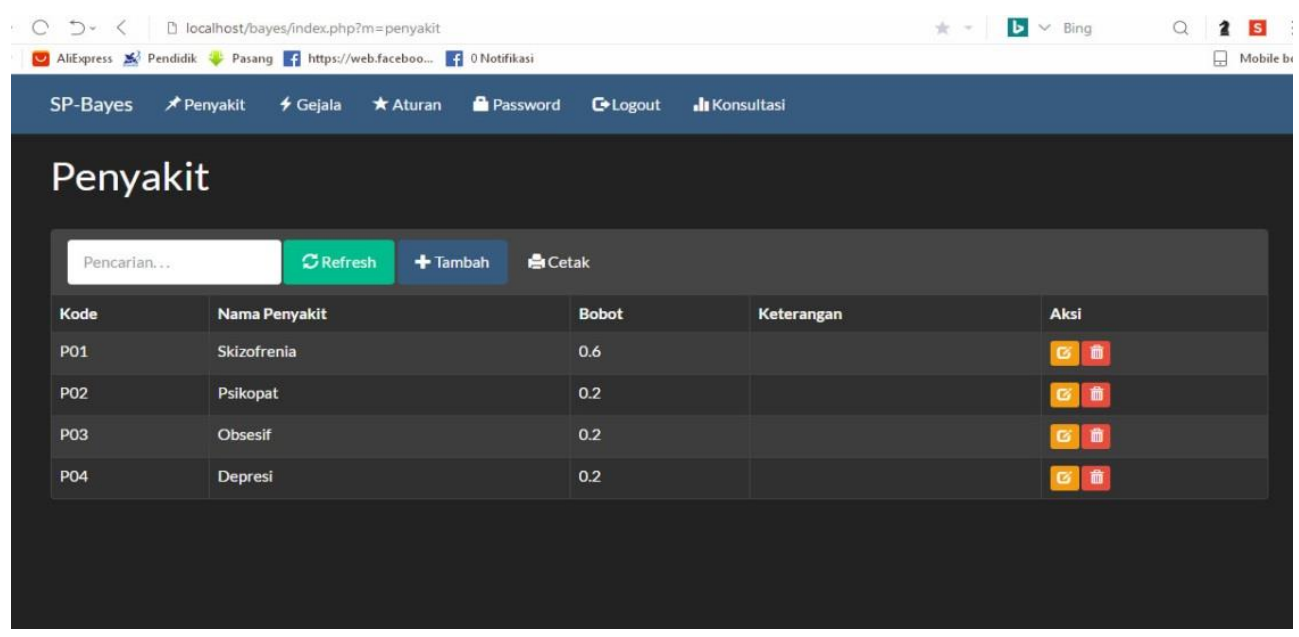

Gambar 2. Tampilan Menu Penyakit 


\section{Menu Gejala}

Halaman menu ini berfungsi untuk memasukan data-data gejala dari jenis penyakit tadi, untuk penginputan data gejala diinput secara acak

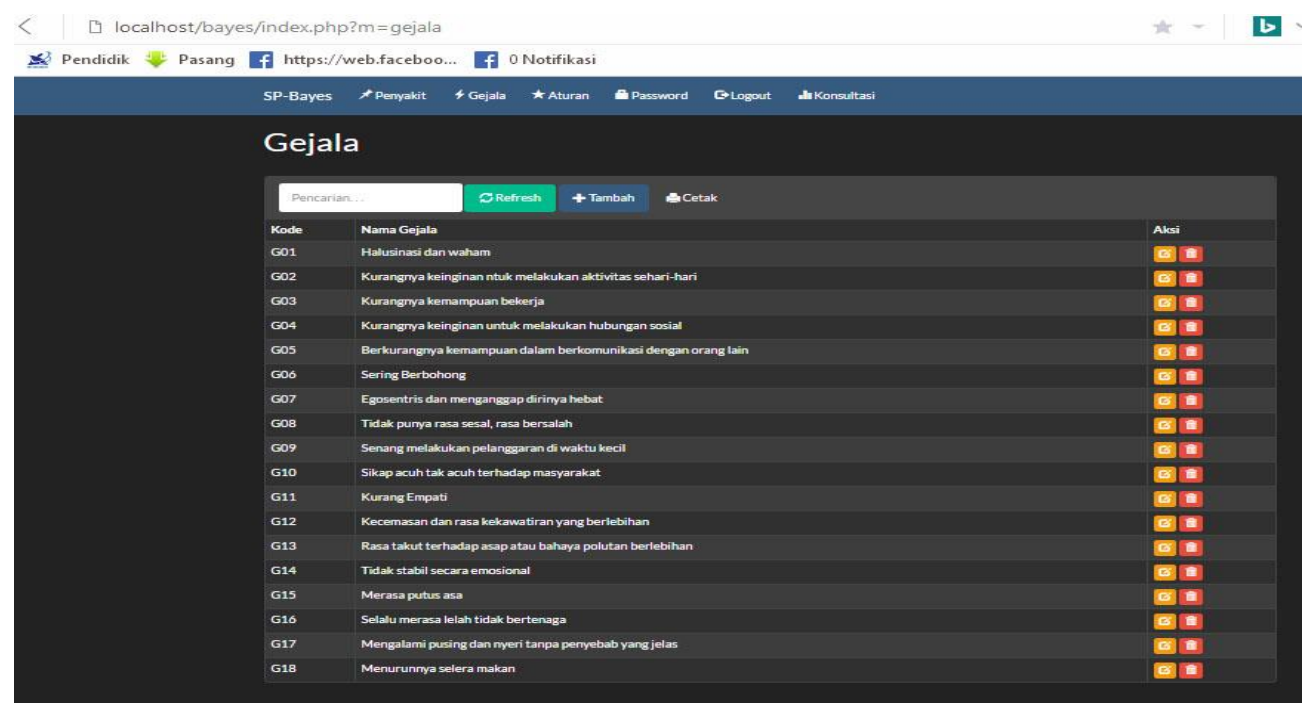

Gambar 3. Tampilan Menu Gejala

\section{Form Setting Aturan}

Pada form ini kita mulai mengaitkan antara penyakit dengan gejala dan memberikan penilaian sesuai metode teorama bayes yang kita gunakan

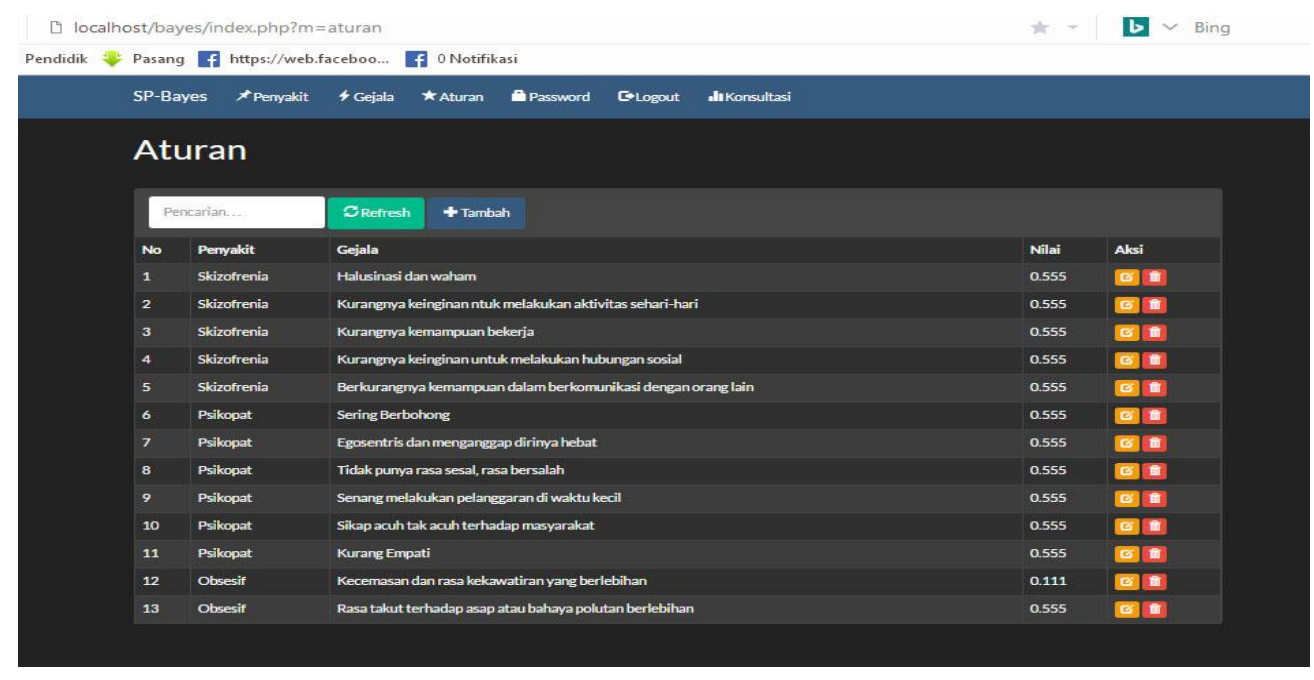

Gambar 4. Tampilan Setting Aturan

\section{Form Konsultasi}

Untuk melakukan proses diagnosa maka silahkan buka halaman konsultasi, pada form konsultasi tinggal memilih dengan cara klik pada checkbox sehingga tanda contreng akan muncul terhadap gejala yang kita rasanya 
endidik Pasang if https://web.faceboo... If 0 Notifikasi

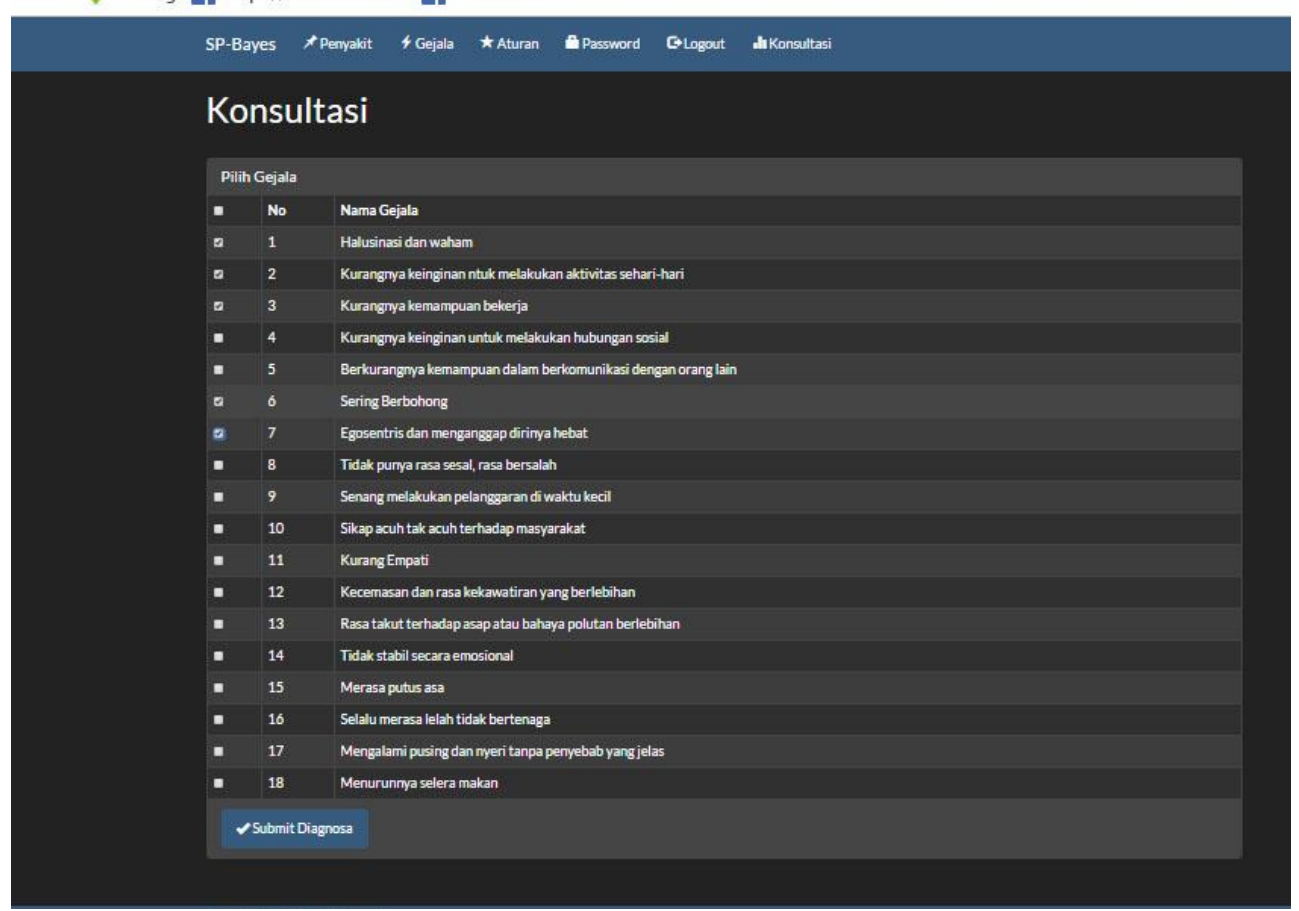

Gambar 5. Tampilan Form Konsultasi

\section{Form Hasil Diagnosa}

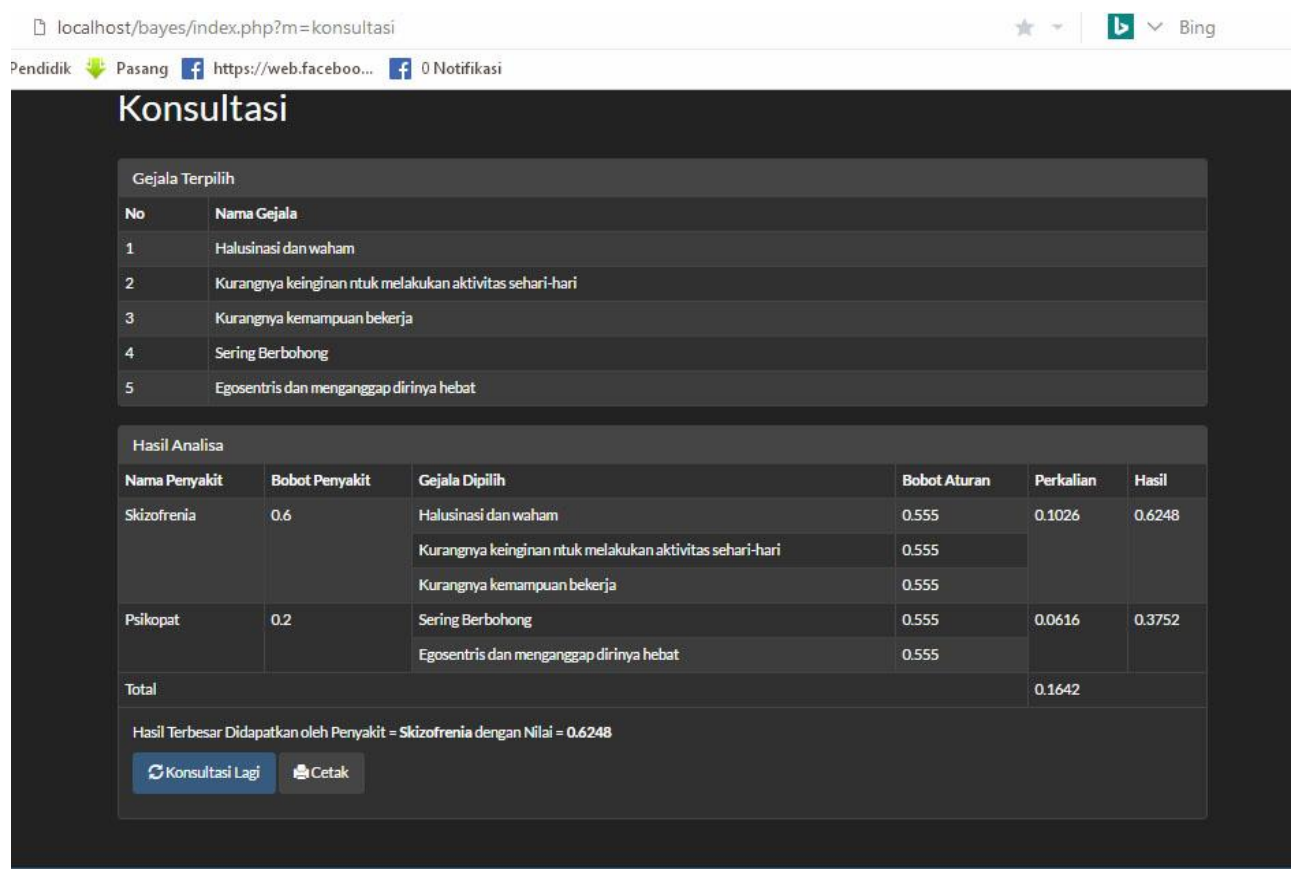

Gambar 6. Tampilan Hasil Diagnosa 


\section{KESIMPULAN}

a. Sistem pakar diagnosa penyakit jiwa, dapat membantu operator klinik didalam penangan cepat dalam mendiagnosa gejala penyakit kejiwaan

b. Dengan adanya sistem pakar menggunakan metode teorama bayes dapat menghitung porsentase besar kemungkinan jenis penyakit dari gejala gejala yang dimasukan

\section{SARAN}

a. Untuk kedepan jenis penyakit jiwa yang dimasukan cakupannya lebih luas lagi

b. Untuk pengembangan teknologi kedepan sebaiknya sistem support android

\section{DAFTAR PUSTAKA}

Agustian, A 2013, Sistem pakar untuk Diagnosis Awal Penyakit Pada Hewan Potong Dengan Menggunakan Teorama Bayes, http://repository.uin-suska.ac.id/id/eprint/1099

Anggara,G 2016, Membangun Sistem Pakar Menggunakan Teorama Bayes Untuk Mendiagnosa Penyakit Paru-paru, https://ojs.amikom.ac.id/index.php/ semnasteknomedia/article/viewFile/1360/1336

Jusniawati, 2013, Aplikasi Sistem Pakar Untuk Mendiagnosa Penyakit Tulang Dengan Menggunakan Metode Bayes, https://media.neliti.com/media/publications/241866-sistem-pakarmenggunakan-teorema-bayes-u-d0cb123a.pdf

Miryanto,B 2014, Sistem Pakar Untuk Mendiagnosa Gangguan Anxietas Dengan Menggunakan Teorama Bayes, http://repository.uinsuska.ac.id/id/eprint/3541

Nugroho, A., \& Wardoyo, R. (2015). Sistem Pakar Menggunakan Teorema Bayes untuk Mendiagnosa Penyakit Kehamilan. BIMIPA, 23(3), 247-254. $/ *$ Retrieved from https://jurnal.ugm.ac.id/bimipa/article/view/13854*/ Retrieved from https://jurnal.ugm.ac.id/bimipa/article/view/13854 